\title{
COMPOSITIONAL AND STRUCTURAL VARIATION OF SUDOITE FROM THE BETIC CORDILLERA (SPAIN): A TEM/AEM STUDY
}

\author{
María Dolores Ruiz Cruz ${ }^{1} *$ and Carlos Sanz de Galdeano \\ ${ }^{1}$ Departamento de Química Inorgánica, Cristalografía y Mineralogía, Facultad de Ciencias, Campus de Teatinos, \\ Universidad de Málaga, Spain \\ ${ }^{2}$ Instituto Andaluz de Ciencias de la Tierra, CSIC-Universidad de Granada, Facultad de Ciencias, 18071 Granada, Spain
}

\begin{abstract}
Sudoite from diagenetic to very low-grade metaclastites of the Betic Cordillera was studied by X-ray diffraction and transmission/analytical electron microscopy. Sudoite formed directly from dickite, the assemblage dickite + sudoite + illite being replaced at increasing metamorphic grade by the assemblage pyrophyllite + sudoite + illite. Sudoite ranges in composition from Mg-rich to Fe-rich chemistries. In addition, a wide variety of mixed-layered structures (illite-sudoite, pyrophyllite-sudoite, and dickitesudoite) was also identified. Mg-rich sudoite shows a mean chemical composition of $\left(\mathrm{Al}_{2.91} \mathrm{Fe}_{0.25}^{2+} \mathrm{Mg}_{1.80}\right)\left(\mathrm{Si}_{3.10} \mathrm{Al}_{0.90}\right) \mathrm{O}_{10}(\mathrm{OH})_{8}$, and a $\mathrm{II} b$ ordered structure with $b=9.055 \AA$. Intermediate $\mathrm{Fe}-\mathrm{Mg}$ sudoite exhibits a very variable composition, the Fe-rich phases having a mean composition of $\left(\mathrm{Al}_{2.09} \mathrm{Fe}_{0.61}^{3+} \mathrm{Fe}_{0.87}^{2+} \mathrm{Mg}_{1.44}\right)\left(\mathrm{Si}_{3.31} \mathrm{Al}_{0.69} \mathrm{O}_{10}(\mathrm{OH})_{8}\right.$. These are disordered polytypes with $b$ values ranging from 9.070 to $9.101 \mathrm{~A}$. Fe occurs in both octahedral sheets, according to two types of substitutions: $\mathrm{Fe}^{3+}$ for $\mathrm{Al}$ in the dioctahedral sheet and $\mathrm{Fe}^{2+}$ for $\mathrm{Mg}$ in the trioctahedral sheet. Sudoite with such a composition has not been described previously.
\end{abstract}

Key Words-Betic Cordillera, Dickite, Illite, Mixed-layer, Pyrophyllite, Spain, Sudoite.

\section{INTRODUCTION}

Di,trioctahedral chlorite with a dioctahedral 2:1 layer and a trioctahedral interlayer is named sudoite (Engelhardt et al., 1962; Eggleton and Bailey, 1967; Bailey, 1980; Lin and Bailey, 1985). Sudoite is essentially Mg-rich and Li-free and has been structurally interpreted as a II $b$ type, with an ideal formula of $\left(\mathrm{Al}_{3} \mathrm{Mg}_{2}\right)\left(\mathrm{Si}_{3} \mathrm{Al}\right) \mathrm{O}_{10}(\mathrm{OH})_{8}$, although the natural sudoites reported in the literature differ significantly from this ideal composition (Bailey, 1980; Bailey and Lister, 1989; Billault et al. 2002). Chemical variations mainly affect the $\mathrm{Si}$ and $\mathrm{Al}$ contents and the $\mathrm{Al} / \mathrm{Mg}$ ratio. Nevertheless sudoites can also show a range of $\mathrm{Fe} /$ $(\mathrm{Fe}+\mathrm{Mg})$ values and $\mathrm{Fe}^{3+} / \mathrm{Fe}^{2+}$ ratios, the $\mathrm{Fe}$ content reaching up to 0.57 a.p.f.u. (atoms per formula unit, calculated for $\mathrm{O}_{10}(\mathrm{OH})_{8}$ ) (Billault et al. 2002).

Although sudoite was initially recognized in association with ore deposits (e.g. Bailey and Tyler, 1960; Hayashi and Oinuma, 1964; Sudo and Sato, 1966), it has also been reported in diagenetic and low-grade metamorphic terrains (e.g. Fransolet and Bourguignon, 1978; Daniels and Altaner, 1990; Livi et al. 2002; Theye and Siedel, 1993). In some cases it is associated with low-temperature, highpressure assemblages (Theye et al., 1992).

In the Betic Cordillera, sudoite has been identified in Triassic sequences from the transition MaláguideAlpujárride Complexes (Abad et al. 2003; Lázaro et al. 2003; Ruiz Cruz et al., 2005). Sudoite is common in

* E-mail address of corresponding author: mdruiz@uma.es

DOI: $10.1346 / \mathrm{CCMN} .2005 .0530610$ fine-grained rocks (red lutites - typical from the Maláguide complex, and blue phyllites - typical of the Alpujárride complex), and less frequent in red sandstones and conglomerates interbedded with red lutites in rocks lithologically similar to the Maláguide complex.

Nevertheless, two contrasting interpretations have been made about the origin of sudoite in these Triassic sequences. In fine-grained rocks from the eastern part of the Cordillera (Sierra Espuña), Abad et al. (2003) interpreted sudoite as a retrograde product of trioctahedral chlorite, based on transmission electron microscopic (TEM) observations. In contrast, in the central part of the Cordillera (Sierra Arana), Ruiz Cruz et al. (2005) interpreted sudoite as formed from dickite during the prograde stage of metamorphism. This interpretation was based on chemical analyses of bulk rocks and on textural evidence observed by optical microscopy.

This work summarizes the transmission/analytical electron microscopic (TEM/AEM) study of sudoite from several mineral associations observed in the sequences of Sierra Arana (Ruiz Cruz et al., 2005), and reveals the presence of sudoites with $\mathrm{Fe}$ contents greater than those previously described. In addition, this work shows that microscopic and submicroscopic sudoites include different types of interstratifications, and this probably explains the chemical variability observed among microprobe analyses of sudoite from different sources.

\section{GEOLOGICAL SETTING AND MATERIALS}

The Internal zone of the Betic Cordillera, in southern Spain, comprises three juxtaposed nappes, which from 
bottom to top are: (1) Nevado-Filábride, (2) Alpujárride, and (3) Maláguide. Subdivision between the Alpujárride and Maláguide complexes has been based mainly on lithostratigraphic characteristics and contrasting grade of metamorphism. The Alpujárride complex shows sequences comprising Paleozoic to Triassic rocks. The Triassic terrains are characterized by the presence of blue phyllites, blue-to-white schists and calc-schists, quartzites and marbles. The Paleozoic rocks are mainly schists, which evolve with depth toward gneisses or even migmatites, depending on the location of the sequences. Both Triassic and Paleozoic rocks show an Alpine lowtemperature/high-pressure metamorphism, overprinted by a high-temperature/low-pressure metamorphism (Azañón, 1994).

The Maláguide complex includes sediments from Paleozoic to Tertiary ages. The Triassic sequences, characterized by the presence of red conglomerates, red sandstones, red lutites and minor carbonates, show a transition from low diagenesis to low anchizone (Ruiz Cruz and Rodríguez Jiménez, 2002). The Paleozoic sequences mainly consist of blue phyllites, limestones, and a greywacke-shale alternation. Two metamorphic stages have been identified in the Maláguide Paleozoic: the Hercynian and the Alpine (Mäkel, 1985). The Alpine parageneses range from the chlorite to the biotite zones (Ruiz Cruz \& Rodríguez Jiménez, 2002). In addition, 'intermediate units' between the Maláguide and the Alpujárride complexes have been described in different zones of the Betic Cordillera (Sanz de Galdeano et al., 2001).

In the central area of the Betic Cordillera (Sierra Arana), the intermediate units, previously characterized by Sanz de Galdeano et al. (1995a, 1995b, 1995c), have been sampled in two sectors: Diezma and El Molinillo
(Figure 1). In both cases, the intermediate units appear as several tectonic slices (from several tens to several hundreds of meters thick), showing a progressive increase in metamorphic grade from the top to the base of the pile. These tectonic slices exhibit notable horizontal continuity. The uppermost tectonic slices show lithological characteristics similar to the typical Maláguide complex whereas increase in depth is characterized by the presence of intermediate lithologies, and finally, by lithologies typical of the Alpujárride complex, in the deepest slices.

In both sectors we have carried out a detailed study by X-ray diffraction (XRD) and electron microprobe of the Triassic materials in the several slices (Ruiz Cruz et al. 2005). A complete sequence of mineral assemblages, ranging from late diagenesis to epizone was identified. The dickite-bearing assemblage, characteristic of the Maláguide-type lithologies, is replaced, at increasing tectonic depth, by the sudoite \pm pyrophyllite assemblage, and this in turn by the trioctahedral chlorite \pm paragonite \pm chloritoid assemblage, characteristic of the Alpujárride-type rocks.

From this study, three samples with different lithologies and mineral associations were selected for TEM/AEM investigation.

\section{ANALYTICAL METHODS}

We report here the results of the study by TEM/AEM. In addition we include some XRD patterns which illustrate the mineralogical compositions of the rocks selected and some structural characteristics of the phyllosilicates.

For the TEM/AEM study, slices were removed from petrographic thin-sections and thinned to electron

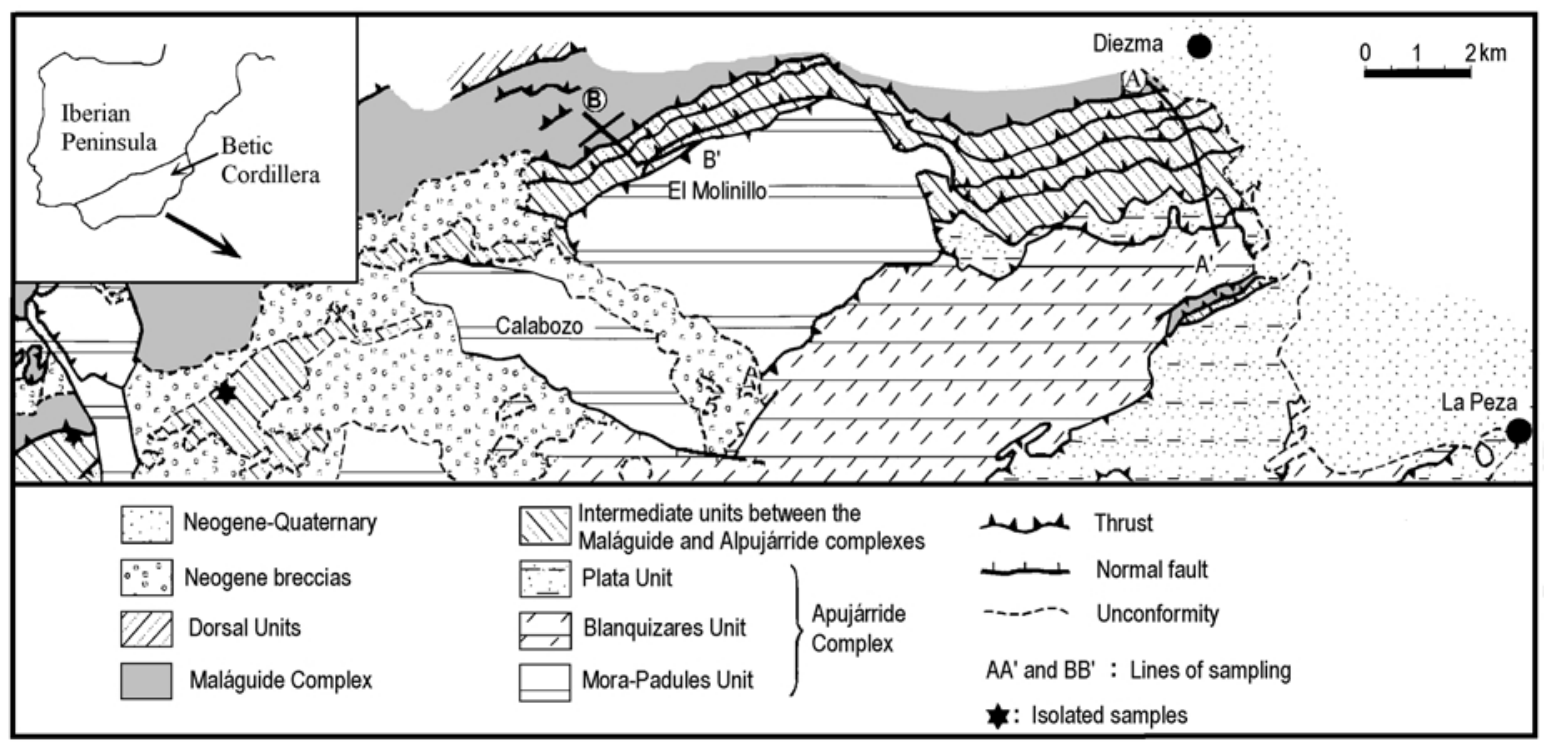

Figure 1. Tectonic map of the area studied and location of the sections. AA': Diezma section. BB': El Molinillo section. 
transparency by argon ion-milling, using a GATAN DUAL Ion Mill-600. Specimens were coated with carbon and examined using a $200 \mathrm{kV}$ Jeol $2000 \mathrm{FX}$ microscope, coupled with a Kevex Quantum X-ray energy-dispersion spectroscopic system (University Complutense, Madrid), and a Philips CM-20 transmission electron microscope, equipped with an EDAX solidstate EDX detector (University of Granada). Scanning TEM mode was used for quantitative analyses (AEM) of particles using a $40 \AA$ diameter beam and variable scanning area, based on the particle size. Muscovite, albite, spessartine, olivine and titanite were used as standards to calculate $\mathrm{K}$ factors by the thin-film method of Lorimer and Cliff (1976).

The XRD patterns were obtained using a Siemens D-5000 powder diffractometer at Málaga University. For XRD analysis of the fine fractions, oriented samples which were air dried, solvated with ethylene glycol (EG), and heated $\left(550^{\circ} \mathrm{C}\right)$ were used. Semi-quantification of the phyllosilicates involved the intensity factors of Islam and Lotse (1986). Randomly oriented powders of $2-20 \mu \mathrm{m}$ and $<2 \mu \mathrm{m}$ size fractions were used for determination of $b$ parameters of the phyllosilicates. The 211 quartz reflection (1.541 $\AA$ ) was used as an internal standard for the exact determination of the position of the 060 reflections of the phyllosilicates. Oriented samples were scanned from 2 to $30^{\circ} 2 \theta$, using $\mathrm{CuK} \alpha$ radiation at $35 \mathrm{~mA}$ and $40 \mathrm{kV}$, and a graphite monochromator ( step size $=0.02^{\circ} 2 \theta$ and counting time of $2 \mathrm{~s}$ ), as recommended by Kisch (1991). Illite crystallinity (KI) was measured using the method of Kübler (1968), as the width of the $10 \AA$ peak at half maximum peak height expressed in ${ }^{\circ} 2 \theta$. The illite polytype was determined from the intensity ratio of the 2.80 and $2.58 \AA$ mica peaks in oriented samples, following Maxwell and Hower (1967). Our KI measurements (y) were transformed into CIS values $(x)$ (Warr and Rice, 1994) according to the equation $y=1.23 x-0.07$. Chlorite crystallinity was determined from the $7 \AA$ peak, under the same experimental conditions as the illite.

\section{RESULTS}

\section{$X$-ray diffraction}

The samples selected (Table 1) include a red conglomerate (CL-64) from the El Molinillo section and a red lutite (CL-26) and a red sandstone (CL-34) from the Diezma section. The mineral assemblage is different in these samples. In addition to quartz, Fe oxides (hematite and magnetite), and occasional albite and carbonate, these samples show the following phyllosilicate associations (Figure 2a):

(1) illite + dickite + sudoite

(2) illite + Na-K-illite + sudoite \pm trioctahedral chlorite, and

(3) illite + pyrophyllite + sudoite \pm trioctahedral chlorite.

Assemblages 1 and 2 are typical, but not exclusive of the El Molinillo section, and appear well developed in coarse-grained rocks (conglomerates and sandstones) and in lutites, respectively. Assemblage 3 is typical of the Diezma section, and has been identified in both fineand coarse-grained lithotypes. In coarse-grained rocks sudoite is observed in pores and veins, frequently replacing dickite. Nevertheless, most grains of sudoite show grain sizes insufficient for study by electron microprobe. In fine-grained rocks, sudoite is not discernible by optical microscopy.

The KI values of illite in sudoite-bearing rocks range from 0.31 to 0.48 in the Diezma section to $0.32-0.74$ in El Molinillo. Samples CL-64 $(\mathrm{KI}=0.48)$ and CL-34 $(\mathrm{KI}=0.42)$ can be ascribed to the late diagenetic zone, whereas sample CL-26 shows a KI (0.39) typical of the low anchizone, according to the nomenclature by Merriman and Peacor (1999). On the other hand, the XRD patterns obtained from unoriented samples (not shown) reveal that the illite polytype $1 M$ is dominant in the El Molinillo section and the polytype $2 M_{1}$ in the Diezma section. In addition to typical K-illite, sample CL-26 contains intermediate $\mathrm{Na}-\mathrm{K}$-illite, as deduced from the presence of reflections at $3.26 \AA$ and $1.98 \AA$ (Frey, 1970; Jiang and Peacor, 1993).

Sudoite was identified in the XRD patterns according to the criteria by Eggleton and Bailey (1967) and Bailey and Lister (1989). The XRD patterns of sudoite usually show a distinctly more intense 003 reflection than trioctahedral chlorites, and the 060 reflection at intermediate positions between those of dioctahedral $(1.49-1.50 \AA)$ and trioctahedral $(1.53-1.54 \AA)$ chlorites. Given the presence of some trioctahedral chlorite together with sudoite in samples CL-26 and CL-34, the relative intensities of the basal reflections do not exactly correspond to those of sudoite (Anceau, 1992). The differences observed in the position of the 060 reflection of sudoite (Figure $2 \mathrm{~b}$ ) can be related to different $\mathrm{Fe}$ contents. The XRD pattern of unoriented sample CL-26

Table 1. Lithology and mineral assemblage in the samples studied.

\begin{tabular}{|c|c|c|c|}
\hline Sample & Sequence & Lithology & Mineral assemblage \\
\hline CL-64 & El Molinillo & Red conglomerate & Quartz + dolomite + illite + dickite + sudoite + Fe oxides \\
\hline CL-26 & Diezma & Red lutite & $\begin{array}{l}\text { Quartz }+ \text { albite }+ \text { calcite }+ \text { dolomite }+\mathrm{K} \text {-illite }+\mathrm{Na}-\mathrm{K} \text {-illite }+ \text { sudoite } \\
+ \text { tri, chlorite }+\mathrm{Fe} \text { oxides }\end{array}$ \\
\hline CL-34 & Diezma & Red sandstone & Quartz + illite + sudoite + tri, chlorite + pyrophyllite + Fe oxides \\
\hline
\end{tabular}



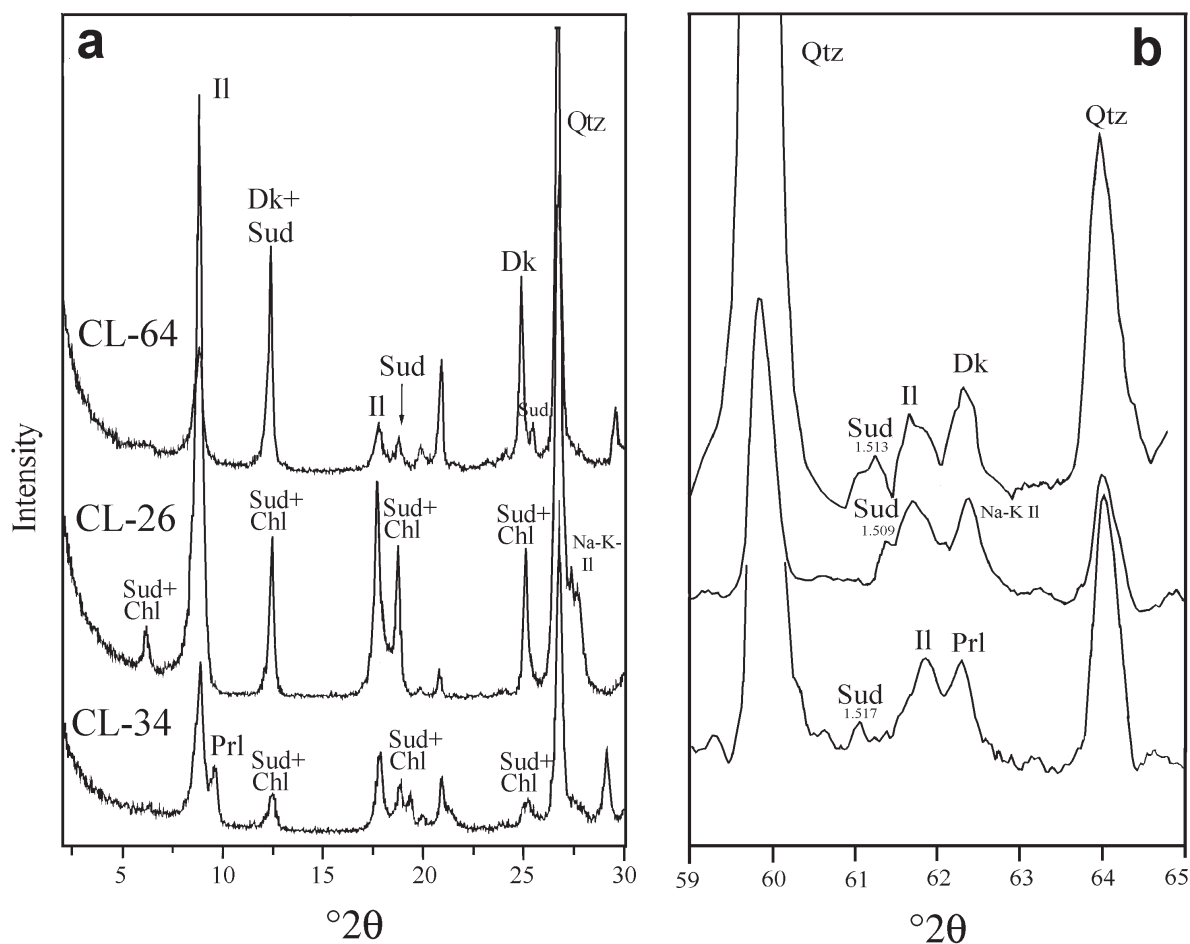

Figure 2. (a) XRD patterns (oriented samples) in the range $2-30^{\circ} 2 \theta$ of the $<2 \mu \mathrm{m}$ size fractions of the samples studied, showing the mineral assemblages. (b) XRD patterns (randomly oriented samples) in the range $59-65^{\circ} 2 \theta$ of the $<2 \mu \mathrm{m}$ size fractions of the samples studied, showing the position of the 060 sudoite reflection. Qtz: quartz. Il: illite. Na-K-Il: sodium potassium illite. Dk: dickite. Sud: sudoite. Prl: pyrophyllite. Chl: trioctahedral chlorite.

shows $20 l(13 l)$ diffraction intensity distribution, characteristic of a II $b$ ordered polytype with $b=9.055 \AA$. The lower sudoite content in the coarse-grained samples has prevented the determination of the sudoite polytype by XRD. The $b$ value in these samples ranges from 9.078 to $9.101 \AA$.

Other structural differences among the described sudoites affect the widths of the $00 l$ basal reflections (crystallinity). Figure 3 shows the XRD patterns of the $<2 \mu \mathrm{m}$ size fractions of samples CL-26 and CL-34, in the zone $11-13^{\circ} 2 \theta$. In sample CL-26, the $7 \AA$ sudoite peak is narrow and symmetrical, whereas in sample CL-34,

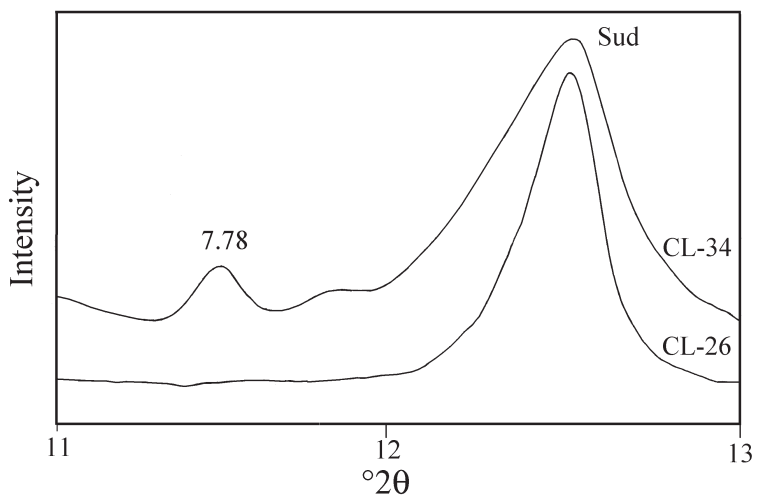

Figure 3. XRD patterns showing the contrasting shapes of the $7 \AA$ reflection of sudoite in samples CL-34 and CL-26. the sudoite peak is broad and asymmetrical, and, in addition, small peaks with higher $d$ values are observed in this zone, the best defined at $7.78 \AA$. This pattern suggests the presence of interstratifications of sudoite and another phase with greater basal spacing.

\section{TEM/AEM study}

Low-magnification observation indicates that sudoite grains, with grain thickness from 0.1 to $0.5 \mu \mathrm{m}$, appear either intergrown with other phyllosilicates (Figure 4), or isolated and included in quartz. In sample CL-64, sudoite appears associated with illite or dickite, whereas in samples CL-26 and CL-34, sudoite appears intergrown with illite or illite and pyrophyllite, respectively. In most cases, sudoite appears in the external parts of the composite packets, also in contact with quartz, suggesting a genetic link between quartz and sudoite.

In sample CL-26, sudoite packets are of the order of $0.5 \mu \mathrm{m}$ thick and generally show high-angle boundaries with illite (Figure $4 \mathrm{~b}$ ), displaying variable composition from K-rich particles to $\mathrm{Na}-\mathrm{K}$ intermediate particles. Large crystals of sudoite show lattice-fringe images with regular $14 \AA$ or $28 \AA$ periodicities and SAED patterns characteristic of either one-layer or two-layer ordered polytypes (Figure 5a). The presence of $10 \AA$ fringes interstratified in the sudoite structure is only rarely observed (Figure 5b). Some representative AEM data for sudoite from this sample are shown in Table 2. The 

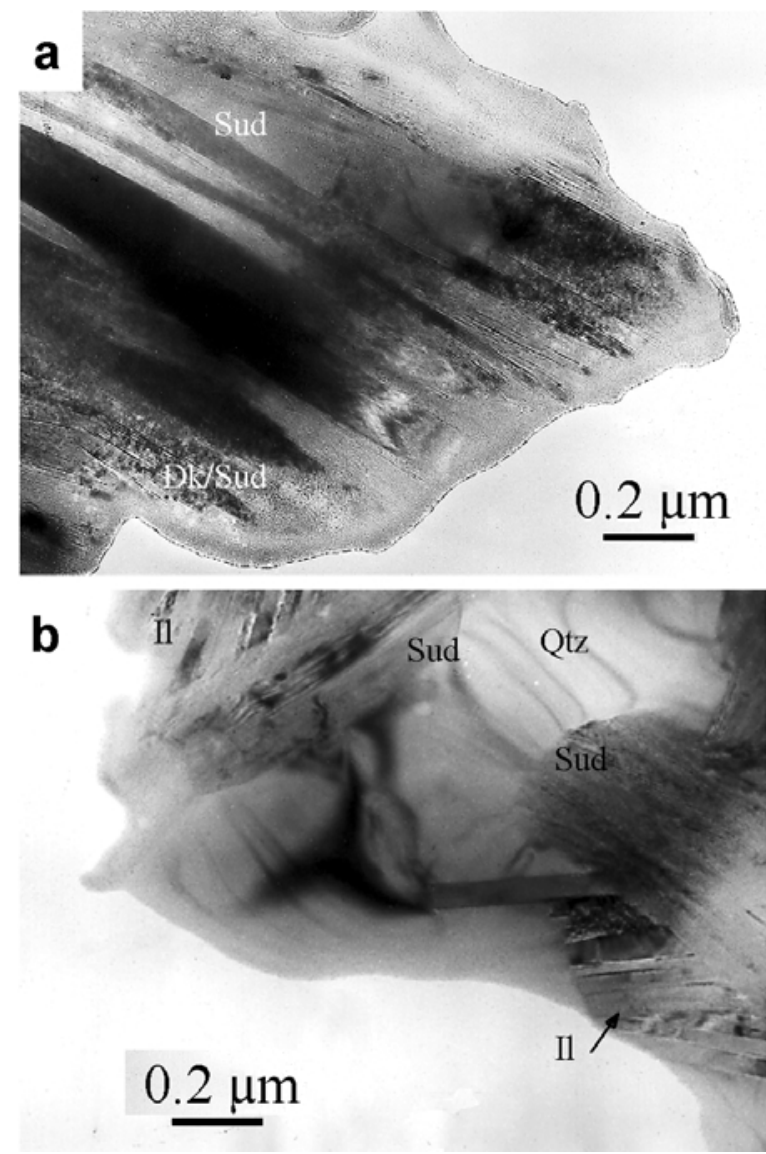

Figure 4. Low-magnification TEM images showing a composite grain sudoite-dickite (a) (sample CL-64) and the sudoite + illite assemblage (b) (sample CL-26). Qtz: quartz. Il: illite. Dk: dickite. Sud: sudoite.

formulae calculated for $\mathrm{O}_{10}(\mathrm{OH})_{8}$ and assuming all $\mathrm{Fe}$ as ferrous reveal that the $\mathrm{Si}$ content ranges from 2.96 to 3.20. Sudoite is also characterized by a low $\mathrm{Fe} /(\mathrm{Fe}+\mathrm{Mg})$ ratio, which ranges between 0.09 and 0.14 . These values are close to those described for conventional sudoites (Billault et al. 2002, and references therein). Small amounts of $\mathrm{Na}$ or $\mathrm{K}$ in some analyses reveal the presence of mica layers interstratified in sudoite.

Lattice-fringe images of packets with chemical compositions near that of sudoite show a variety of structures in coarse-grained rocks (CL-34 and CL-64). Images with regular $14 \AA$ periodicity are relatively scarce. The coarsest packets $(\sim 0.5 \mu \mathrm{m}$ thick $)$ were observed in sample CL-64 (Figure 6a). The SAED patterns obtained from these packets (Figure 6a, inset), show a $14 \AA$ periodicity along $c^{*}$ and poorly defined reflections in the $0 \mathrm{kl}$ or $h \mathrm{hl}$ reflection rows, reflecting abundant stacking disorder. These packets show a variable composition as shown in the AEM data in Table 3 (analyses 1-6). The formulae calculated for $\mathrm{O}_{10}(\mathrm{OH})_{8}$ and assuming all $\mathrm{Fe}$ as ferrous reveal that $\mathrm{Si}$ content ranges from 3.26 to 3.46 a.p.f.u. Although the $\mathrm{Fe}+\mathrm{Mg}$ content varies considerably, the $\mathrm{Fe} /(\mathrm{Fe}+\mathrm{Mg})$ ratio is rather constant $(0.27-0.32)$ and greater than that measured in the fine-grained sample. The total octahedral occupancy ranges from 4.79 to 5.20 , within the compositional range of sudoite (Bailey, 1980).

Some crystals from this sample show significant chemical deviations from the described composition. These deviations include a high $\mathrm{Al}$ content accompanied by a decrease in $\mathrm{Fe}+\mathrm{Mg}$ content (Table 3, analyses 7-9), suggesting the presence of dickite/sudoite intergrowths or interstratifications. The lattice-fringe images from these areas show a uniform $14 \AA$ periodicity. Nevertheless, medium magnification images occasionally permit the observation of thin packets $(\sim 200-500 \AA$ thick) showing fringes with 42 and $56 \AA$ periodicities (Figure 6b) which suggest the presence of interstratifications of one sudoite + two dickite (or two sudoite + one dickite) layers and two sudoite + two dickite layers.

Lattice-fringe images of sudoite from sample CL-34 show small areas with a $14 \AA$ periodicity which evolve laterally toward areas with more complex structures. The AEM data obtained from the $14 \AA$ areas show, however, a wide compositional variability which mainly affects the $\mathrm{Si}$ content and the $\mathrm{Fe} /(\mathrm{Fe}+\mathrm{Mg})$ ratio (Table 4, analyses 1-6). The $\mathrm{Si}$ content ranges from 3.17 to 3.56 a.p.f.u., whereas the $\mathrm{Fe} /(\mathrm{Fe}+\mathrm{Mg})$ ratio ranges between 0.37 and 0.59 . These latter values are notably larger than the values commonly determined for sudoite (Newman and Brown, 1987). The total octahedral occupancy ranges between 5.02 and 5.32 when the formulae are calculated assuming all $\mathrm{Fe}$ as ferrous. These values are slightly higher than the ideal value for

Table 2. Representative chemical composition for sudoite (calculated for $\mathrm{O}_{10}(\mathrm{OH})_{8}$ ) from sample CL-26.

\begin{tabular}{lcccccccc}
\hline & 1 & 2 & 3 & 4 & 5 & 6 & 7 & 8 \\
\hline${ }^{\mathrm{IV}} \mathrm{Si}$ & 2.96 & 3.01 & 3.05 & 3.10 & 3.11 & 3.16 & 3.17 & 3.20 \\
${ }^{\mathrm{IV}} \mathrm{Al}$ & 1.04 & 0.99 & 0.95 & 0.90 & 0.89 & 0.84 & 0.83 & 0.80 \\
${ }^{\mathrm{VI}} \mathrm{Al}$ & 2.77 & 2.86 & 2.91 & 2.93 & 2.92 & 3.00 & 2.91 & 2.98 \\
$\mathrm{Fe}$ & 0.22 & 0.20 & 0.27 & 0.27 & 0.27 & 0.19 & 0.28 & 0.28 \\
$\mathrm{Mg}$ & 2.17 & 1.91 & 1.78 & 1.80 & 1.75 & 1.66 & 1.66 & 1.68 \\
$\mathrm{Na}$ & 0.00 & 0.00 & 0.00 & 0.00 & 0.05 & 0.09 & 0.23 & 0.00 \\
$\mathrm{~K}$ & 0.04 & 0.05 & 0.06 & 0.00 & 0.02 & 0.06 & 0.00 & 0.00 \\
$\mathrm{Fe} /(\mathrm{Fe}+\mathrm{Mg})$ & 0.09 & 0.09 & 0.13 & 0.13 & 0.13 & 0.10 & 0.14 & 0.14 \\
$\mathrm{\Sigma oct}$ & 5.16 & 4.97 & 4.96 & 5.00 & 4.96 & 4.85 & 4.85 & 4.94 \\
& & & & & & & & \\
\hline
\end{tabular}




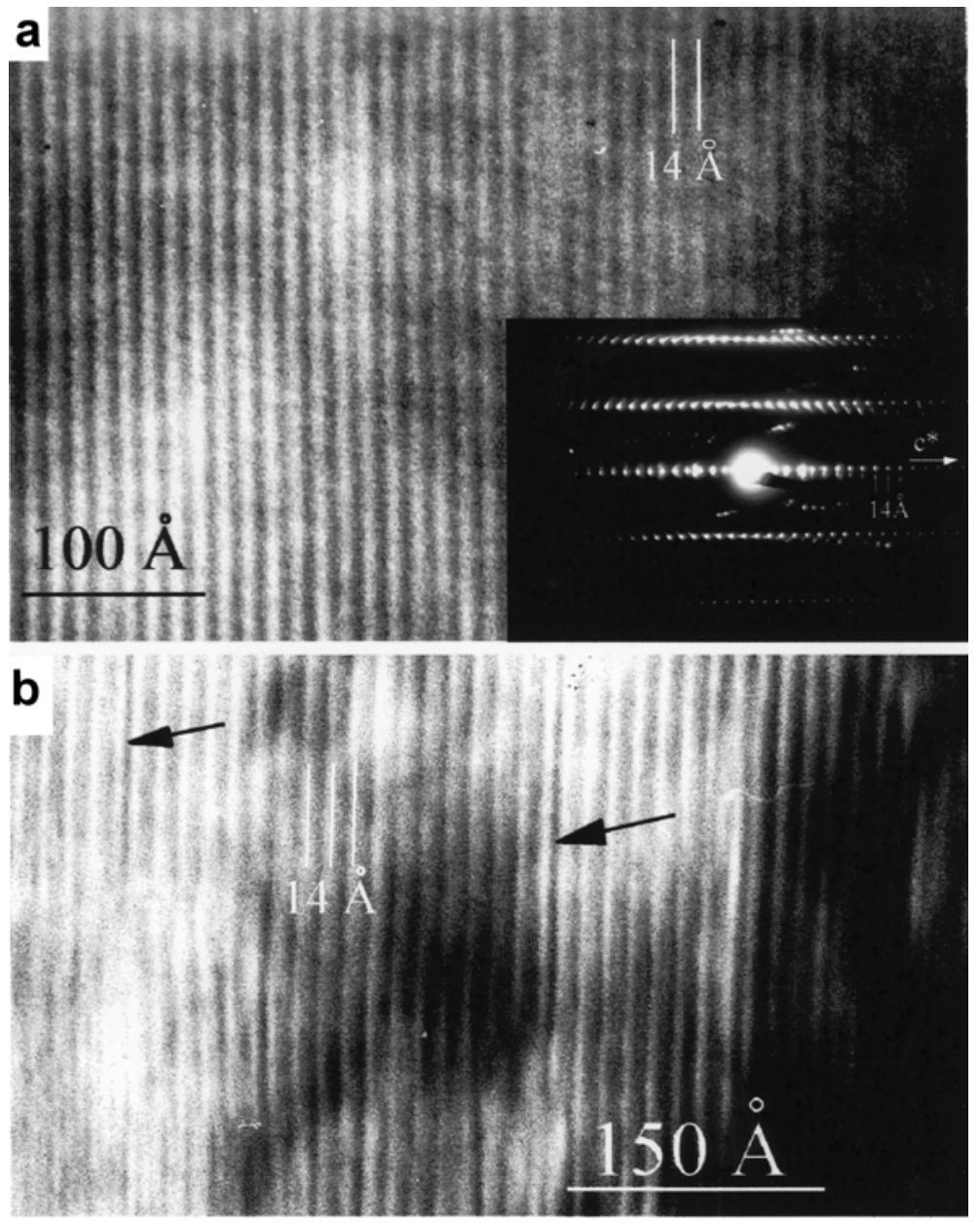

Figure 5. Lattice-fringe images of sudoite from sample CL-26. (a) Packet with regular $14 \AA$ A periodicity. The SAED pattern, viewed along the 110 zone axis, indicates the presence of an ordered polytype. (b) This image shows the presence of scarce $10 \AA$ fringes (arrows) randomly interstratified in the sudoite structure.

sudoite, suggesting that some $\mathrm{Fe}$ can be $\mathrm{Fe}^{3+}$. Indeed, previous studies of sudoite indicate that in oxidizing conditions, the $\mathrm{Fe}^{3+}$ content can be high (e.g. Billault et al. 2002). With the aim of estimating the $\mathrm{Fe}^{3+} / \mathrm{Fe}^{2+}$ ratio, the sudoite analyses from this sample were also tentatively normalized to 14 oxygens and 9 cations (Table 4). Following this method, the formulae obtained indicate the presence of both $\mathrm{Fe}^{2+}$ and $\mathrm{Fe}^{3+}$ in variable proportions.

In most cases, sudoite packets with a dominant $14 \AA$ periodicity contain randomly distributed $10 \AA$ layers (Figure 7a). These packets show compositions characterized by small but persistent amounts of $\mathrm{K}$ (in the order of 0.1 a.p.f.u.), as observed in Table 4 (analyses 4-6).

Table 3. Representative chemical composition for sudoite and mixed layers (calculated for $\left.\mathrm{O}_{10}(\mathrm{OH})_{8}\right)$ from sample CL-64.

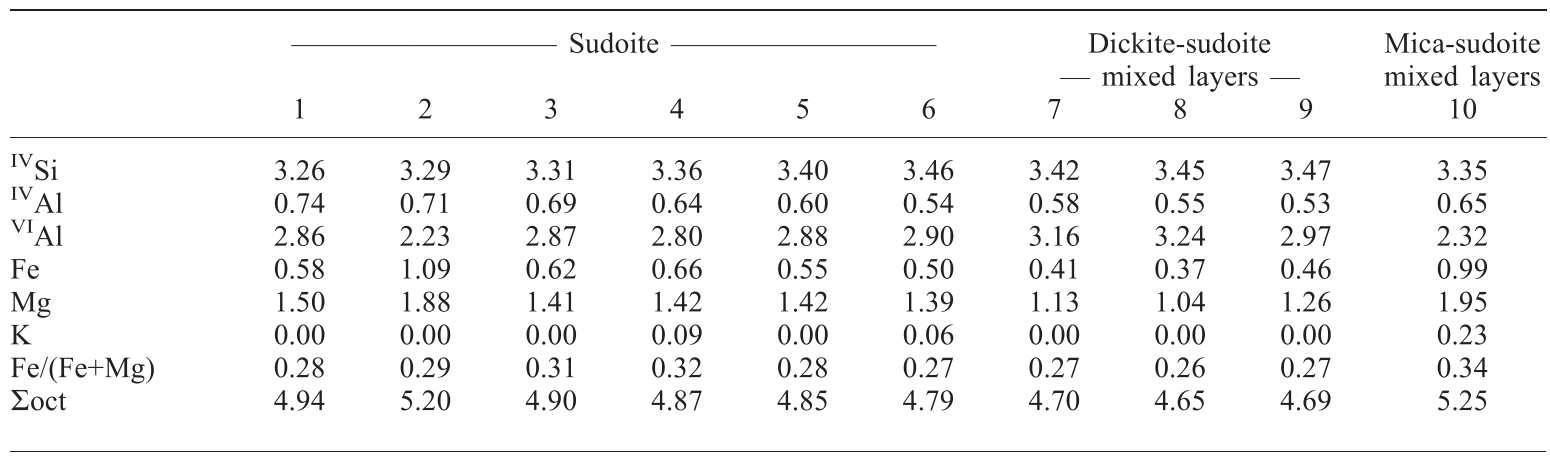



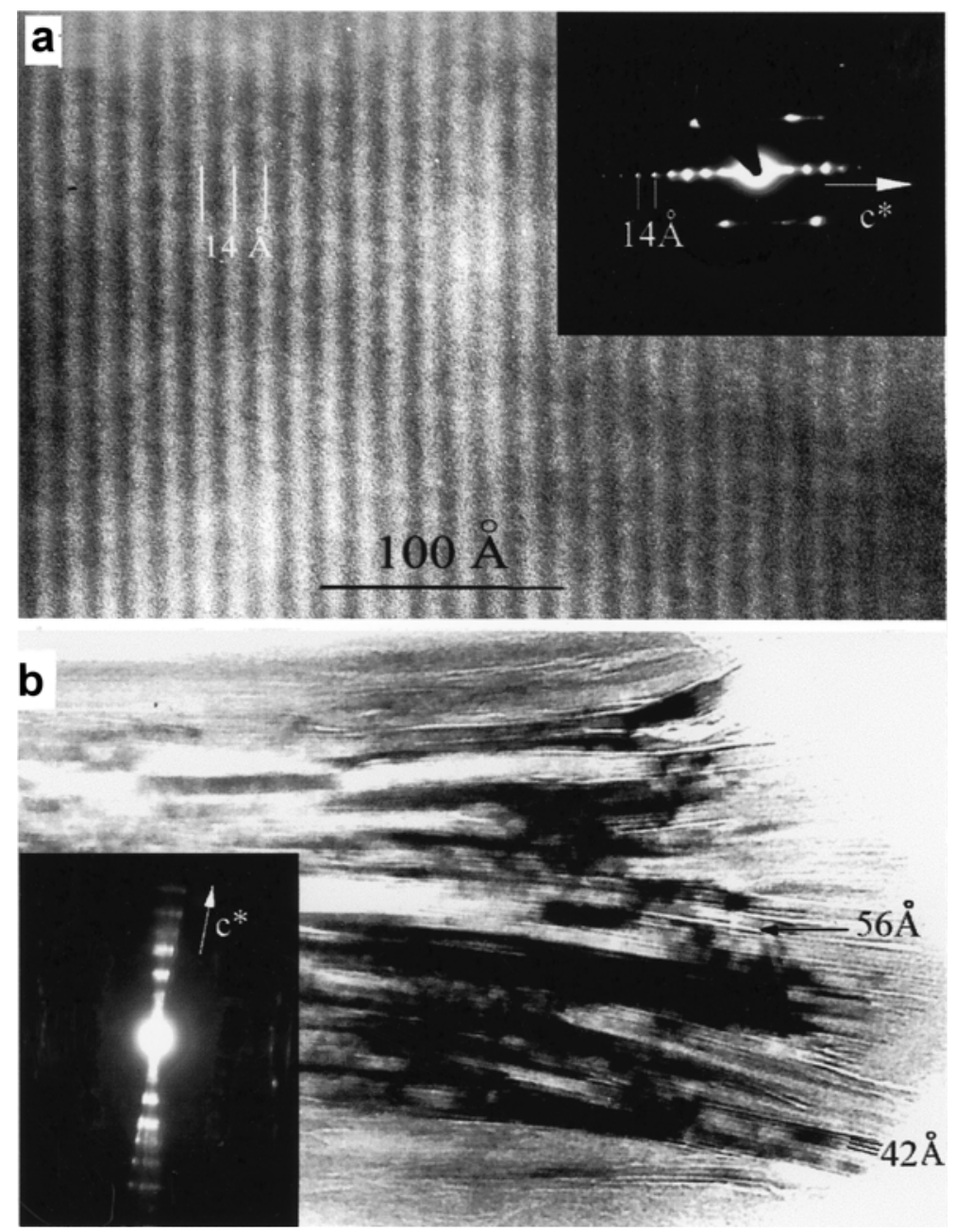

Figure 6. (a) Lattice-fringe image of a sudoite crystal from sample CL-64, showing the regular $14 \AA$ periodicity. The SAED pattern, viewed along the 110 zone axis, indicates the presence of a disordered polytype. (b) Medium-magnification image of a composite dickite-sudoite grain with dominant $42 \AA$ periodicity. The SAED pattern shows a main $14 \AA$ A periodicity and streaking along $c^{*}$.

An increase in the proportion of mica layers interstratified in the sudoite structure generates mica-sudoite interstratifications with dominant 24 and $38 \AA$ periodicities, corresponding to one sudoite + one mica layer and two sudoite + one mica layer, respectively (Figure 7b). The SAED patterns show a dominant $24 \AA$ periodicity. The composition of these interstratified structures is characterized by an increase in $\mathrm{K}$ content (Table 4, analyses 7-9). The formulae have also been calculated for $\mathrm{O}_{10}(\mathrm{OH})_{8}$. These formulae are unrealistic but permit the comparison with sudoite formulae. Chemical variability in these structures mainly affects the $\mathrm{Fe} /(\mathrm{Fe}+\mathrm{Mg})$ ratio $(0.44-0.62)$.

Another type of interstratification has been observed in sample CL-34. The lattice-fringe images are similar to those of the mica-sudoite packets, but the AEM data indicate that the $\sim 10 \AA$ layers are not mica but pyrophyllite. In these packets, areas with random-toregular interstratifications appear intergrown with thin areas of pyrophyllite and sudoite (Figure 8). The SAED patterns obtained from these packets commonly show reflections of sudoite and pyrophyllite. Most of the analyses of these packets (Table 4, analysis 10-12) are characterized by an increase in Si content relative to sudoite and mica-sudoite interstratifications coupled with a decrease in $\mathrm{Fe}+\mathrm{Mg}$ content. Some of these packets, however, show a low K-content, suggesting the presence of both pyrophyllite and mica layers interstratified with sudoite.

The phyllosilicates coexisting with sudoite were also investigated by TEM/AEM, although we only report here a summary of these results. Dickite, previously characterized by XRD, is abundant in sample CL-64 where it forms coarse packets with a well defined 7 (or 14) $\AA$ periodicity. The $0 k l$ and $h h l$ reflection rows confirm the presence of a two-layer polytype (Figure 9a). The composition is almost stoichiometric, with only 0.01 a.p.f.u. of $\mathrm{Fe}$ (Table 5).

In sample CL-64, the white mica yields SAED patterns characteristic of a $1 M$ polytype (Figure $9 \mathrm{~b}$ ). 
Table 4. Representative chemical composition for sudoite and mixed layers (calculated for $\left.\mathrm{O}_{10}(\mathrm{OH})_{8}\right)$ from sample CL-34.

\begin{tabular}{|c|c|c|c|c|c|c|c|c|c|c|c|c|}
\hline & \multirow[b]{2}{*}{1} & \multicolumn{4}{|c|}{ - Sudoite } & \multirow[b]{2}{*}{6} & \multicolumn{3}{|c|}{$\begin{array}{l}\text { Mica-sudoite ML } \\
\text { - mixed layers - }\end{array}$} & \multicolumn{3}{|c|}{$\begin{array}{l}\text { Pyrophyllite-sudoite } \\
\text { _ mixed layers - }\end{array}$} \\
\hline & & 2 & 3 & 4 & 5 & & 7 & 8 & 9 & 10 & 11 & 12 \\
\hline \multicolumn{13}{|c|}{ (a) assuming all $\mathrm{Fe}$ as $\mathrm{Fe}^{2+}$} \\
\hline${ }^{\mathrm{IV}} \mathrm{Si}$ & 3.17 & 3.22 & 3.40 & 3.43 & 3.51 & 3.56 & 3.38 & 3.40 & 3.49 & 3.70 & 3.72 & 3.77 \\
\hline${ }^{\mathrm{IV}} \mathrm{Al}$ & 0.83 & 0.78 & 0.60 & 0.57 & 0.49 & 0.44 & 0.62 & 0.60 & 0.51 & 0.30 & 0.28 & 0.23 \\
\hline${ }^{\mathrm{VI}} \mathrm{Al}$ & 2.14 & 2.23 & 2.18 & 2.26 & 2.24 & 2.20 & 2.33 & 2.26 & 2.09 & 2.30 & 2.19 & 2.72 \\
\hline $\mathrm{Fe}$ & 1.37 & 1.33 & 1.64 & 1.38 & 1.55 & 1.73 & 1.24 & 1.46 & 1.83 & 1.39 & 1.66 & 0.82 \\
\hline $\mathrm{Mg}$ & 1.81 & 1.76 & 1.39 & 1.38 & 1.25 & 1.21 & 1.60 & 1.28 & 1.13 & 1.27 & 1.16 & 1.24 \\
\hline $\mathrm{K}$ & 0.00 & 0.00 & 0.00 & 0.09 & 0.09 & 0.14 & 0.23 & 0.30 & 0.34 & 0.09 & 0.09 & 0.00 \\
\hline $\mathrm{Fe} /(\mathrm{Fe}+\mathrm{Mg})$ & 0.43 & 0.37 & 0.43 & 0.50 & 0.55 & 0.59 & 0.44 & 0.53 & 0.62 & 0.50 & 0.59 & 0.40 \\
\hline Soct & 5.32 & 5.32 & 5.21 & 5.02 & 5.04 & 5.14 & 5.17 & 5.00 & 5.05 & 5.09 & 5.01 & 4.78 \\
\hline \multicolumn{13}{|c|}{ (b) normalized to $\mathrm{O}_{10}(\mathrm{OH})_{8}$ and nine cations } \\
\hline${ }^{\mathrm{IV}} \mathrm{Si}$ & 3.06 & 3.11 & 3.32 & 3.42 & 3.49 & 3.50 & & & & & & \\
\hline${ }^{\mathrm{IV}} \mathrm{Al}$ & 0.94 & 0.89 & 0.68 & 0.58 & 0.51 & 0.50 & & & & & & \\
\hline${ }^{\mathrm{VI}} \mathrm{Al}$ & 1.93 & 2.02 & 2.04 & 2.24 & 2.21 & 2.10 & & & & & & \\
\hline $\mathrm{Fe}^{3+}$ & 1.05 & 0.87 & 0.64 & 0.25 & 0.23 & 0.62 & & & & & & \\
\hline $\mathrm{Fe}^{2+}$ & 0.27 & 0.41 & 0.96 & 0.25 & 0.23 & 0.62 & & & & & & \\
\hline $\mathrm{Mg}$ & 1.75 & 1.70 & 1.36 & 1.38 & 1.24 & 1.19 & & & & & & \\
\hline $\mathrm{K}$ & 0.00 & 0.00 & 0.00 & 0.09 & 0.09 & 0.14 & & & & & & \\
\hline
\end{tabular}
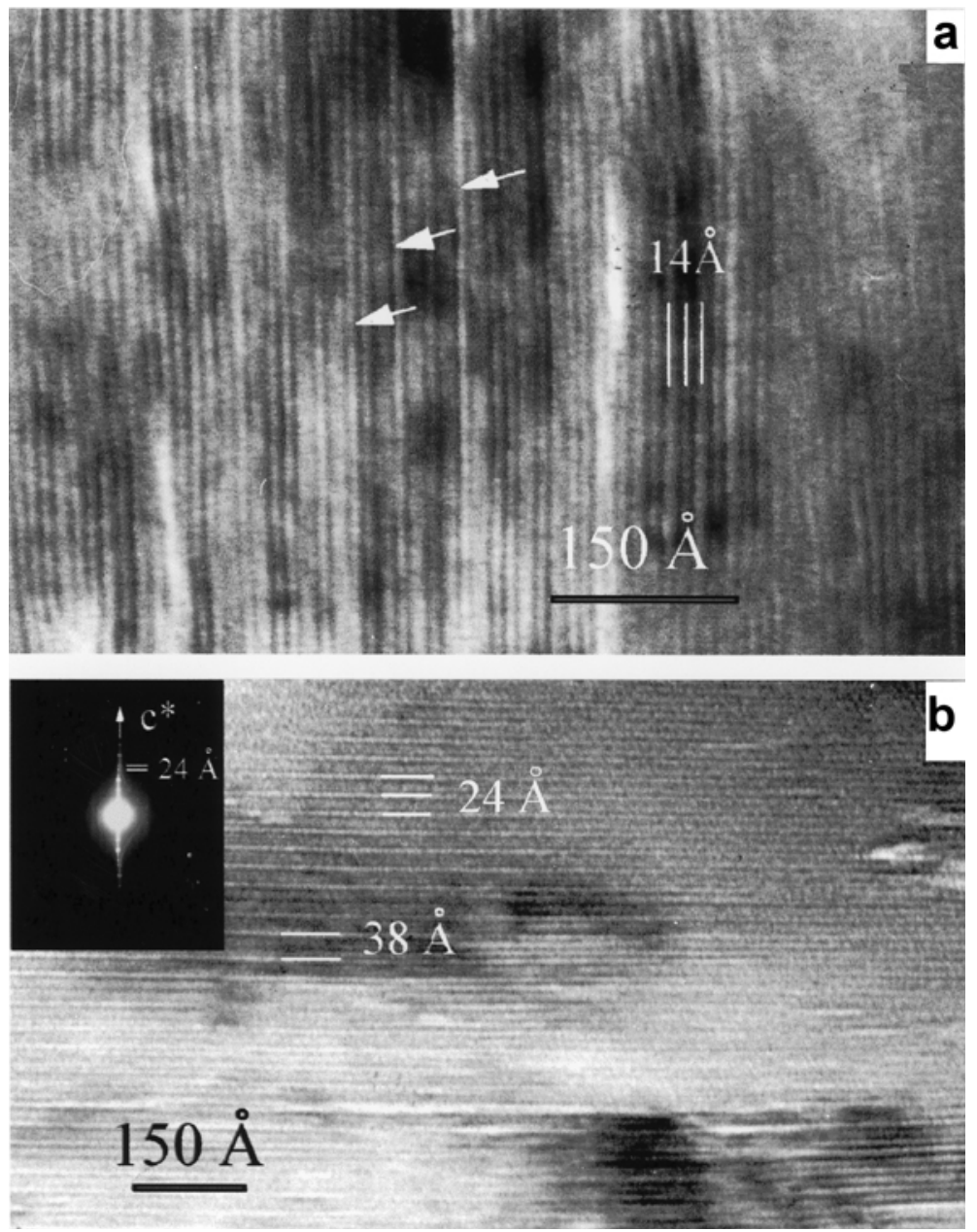

Figure 7. Lattice-fringe images of sudoite from sample CL-34. (a) Randomly interstratified mica-sudoite mixed layers intergrown with sudoite. Arrows indicate the $10 \AA$ fringes. (b) 1:1 and 1:2 mica-sudoite sequences. The SAED pattern shows a $24 \AA$ periodicity. 
Table 5. Representative chemical composition for phyllosilicates coexisting with sudoite.

\begin{tabular}{|c|c|c|c|c|c|c|c|c|c|c|}
\hline \multirow[b]{2}{*}{${ }^{\mathrm{IV}} \mathrm{Si}_{\mathrm{i}}$} & \multicolumn{2}{|c|}{$\begin{array}{l}\text { Dickite } \\
\text { (CL-64) }\end{array}$} & \multirow{2}{*}{$\frac{(\mathrm{CL}-64)}{3.42}$} & $\begin{array}{r}\text { Ill } \\
(\mathrm{CL}-26)\end{array}$ & Illite & (CL-34) & \multicolumn{2}{|c|}{$\begin{array}{l}\text { Pyrophyllite } \\
\text { (CL-34) }\end{array}$} & \multicolumn{2}{|c|}{$\begin{array}{l}\text { Chlorite } \\
\text { (CL-34) }\end{array}$} \\
\hline & 1.98 & 2.02 & & 3.28 & 3.12 & 3.24 & 3.78 & 3.98 & 2.77 & 2.72 \\
\hline${ }^{\mathrm{IV}} \mathrm{Al}$ & 0.02 & 0.00 & 0.58 & 0.72 & 0.88 & 0.86 & 0.22 & 0.02 & 1.23 & 1.28 \\
\hline${ }^{\mathrm{VI}} \mathrm{Al}$ & 1.99 & 1.94 & 1.88 & 1.95 & 1.97 & 1.77 & 1.91 & 1.95 & 1.59 & 1.44 \\
\hline $\mathrm{Fe}$ & 0.01 & 0.01 & 0.09 & 0.02 & 0.06 & 0.08 & 0.03 & 0.10 & 1.82 & 3.23 \\
\hline $\mathrm{Mg}$ & 0.00 & 0.00 & 0.00 & 0.11 & 0.09 & 0.18 & 0.12 & 0.10 & 2.46 & 1.20 \\
\hline $\mathrm{Na}$ & 0.00 & 0.00 & 0.00 & 0.11 & 0.40 & 0.00 & 0.00 & 0.00 & 0.00 & 0.00 \\
\hline K & 0.00 & 0.00 & 0.73 & 0.64 & 0.38 & 0.83 & 0.14 & 0.00 & 0.00 & 0.00 \\
\hline
\end{tabular}

Dickite formulae calculated for $\mathrm{O}_{5}(\mathrm{OH})_{4}$

Illite and pyrophyllite formulae calculated for $\mathrm{O}_{10}(\mathrm{OH})_{2}$

Chlorite formulae calculated for $\mathrm{O}_{10}(\mathrm{OH})_{8}$

The analyses show little variability and are characterized by a high $\mathrm{Si}$ content ( 3.4 a.p.f.u.) (Table 5). In sample CL-26, the SAED patterns of illite (Figure 9c) correspond to a two-layer polytype with some stacking disorder. The AEM data (Table 5) reflect a decrease in $\mathrm{Si}$ relative to the analyses of illite from sample CL-64, and either a K-rich composition or a Na-K composition. Finally, the SAED patterns of illite from sample CL-34 are characterized by the presence of $0 \mathrm{kl}$ or $h \mathrm{hl}$ reflection rows typical of a well-ordered $2 M_{1}$ polytype (Figure 9d). The AEM data correspond to K-rich particles (Table 5).

Pyrophyllite (only present in sample CL-34) forms coarse packets, and the SAED patterns correspond to an ordered two-layer polytype (Figure 9e). Some of the analyses obtained correspond to the ideal formula, whereas others show a slight decrease in $\mathrm{Si}$, accompanied by some K, probably reflecting the presence of layers of white mica interstratified in the pyrophyllite structure.

Finally, trioctahedral chlorite appears in small amounts in samples CL-26 and CL-34. Both optical microscopy and TEM observations indicate that trioctahedral chlorite forms discrete grains, without an apparent relationship with sudoite. Trioctahedral chlorite shows SAED patterns characteristic of either two-layer polytypes or disordered polytypes (Figure 9f). Chlorite analyses show homogeneous $\mathrm{Si}$ and $\mathrm{Al}$ contents, and considerable variation in the $\mathrm{Fe} /(\mathrm{Fe}+\mathrm{Mg})$ ratio, as observed in Table 5.

\section{DISCUSSION}

\section{Crystal chemistry of sudoite and interstratified phases}

Sudoite appears in the rocks examined for this study both as microscopic grains and as submicroscopic packets. Microscopic grains were observed in coarsegrained rocks although they are very scarce (Ruiz Cruz et al. 2005). Submicroscopic packets are the most common in both coarse- and fine-grained rocks. On the other hand, the XRD study also reveals notable differences between sudoites from the different litholo-

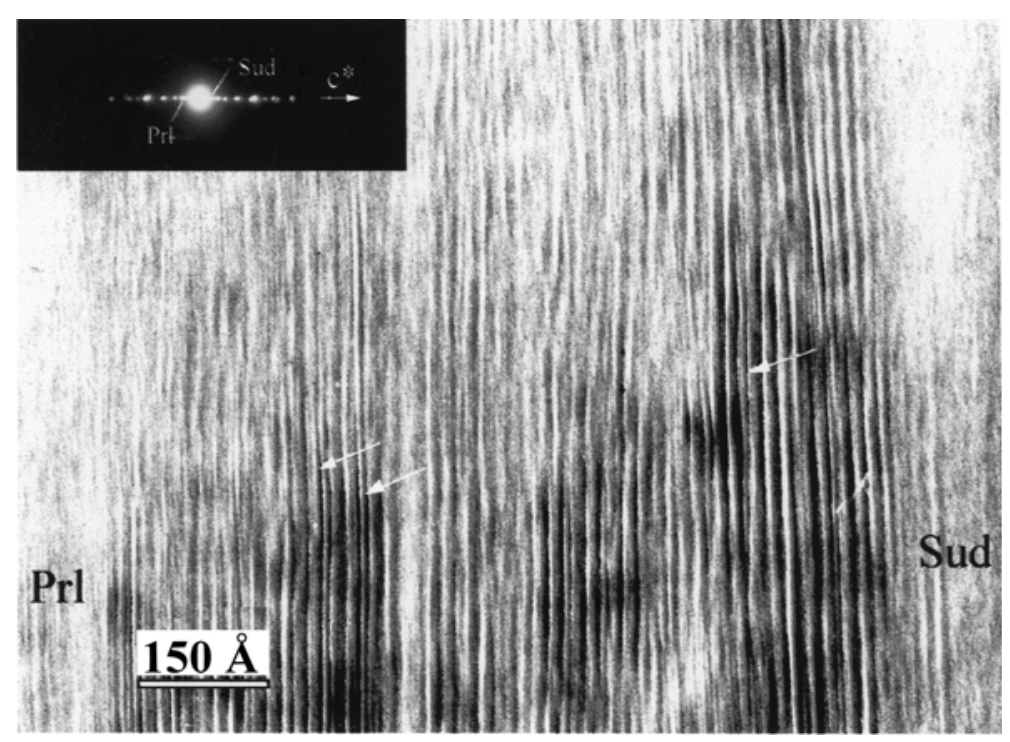

Figure 8. Lattice-fringe image showing intergrowths and interstratified pyrophyllite-sudoite from sample CL-34. The inset SAED pattern shows reflections of sudoite and pyrophyllite. 

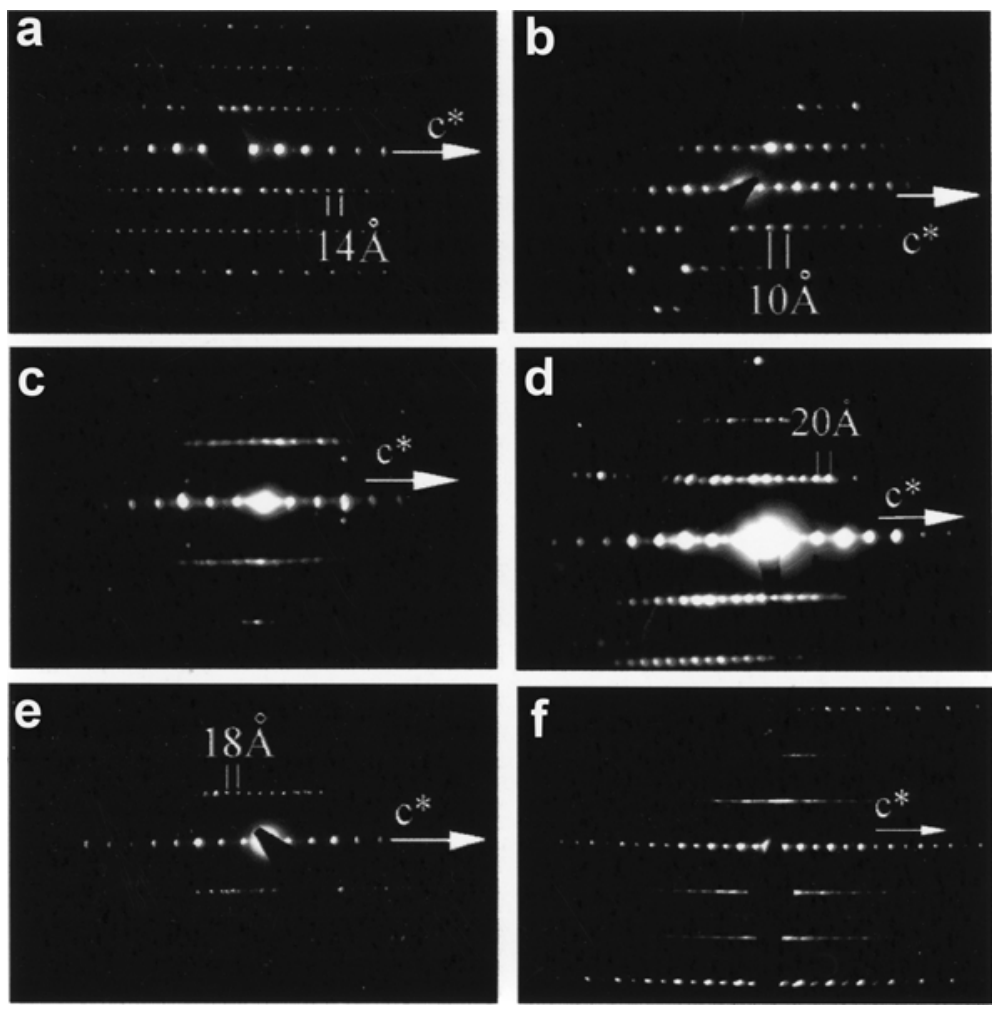

Figure 9. Electron diffraction patterns characteristic of the phyllosilicates coexisting with sudoite in the samples studied. (a) The pattern of dickite, viewed along the 110 zone axis, shows $h$ hl reflection rows with $14 \AA$ periodicity, characteristic of a two-layer polytype (sample CL-64). (b) This pattern of illite, viewed along the 110 zone axis, shows $h h 1$ reflection rows with $10 \AA$ periodicity, characteristic of a $1 M$ polytype (sample CL-64). (c) This pattern of Na-K-illite, viewed along 010 shows $h 0 l$ reflection rows with $20 \AA$ periodicity (sample CL-26). (d) Pattern of K-illite viewed along 110 , showing $h h 1$ reflection rows with $20 \AA$ periodicity, characteristic of a $2 M_{1}$ polytype (sample CL-34). (e) Pattern of pyrophyllite viewed along the 110 zone axis. This shows $h$ hl reflection rows with 18 A periodicity, characteristic of a two-layer polytype (Sample CL-34). (f) Pattern of trioctahedral chlorite (sample CL-34).

gies. These differences mainly affect the $b$ parameter, which is lower in Mg-rich sudoites from the fine-grained sample $(9.055 \AA)$ than in sudoites from coarse-grained samples $(9.070$ to $9.101 \AA)$, and they occur in the dominant polytype, which is $2 M_{1}$ in sample CL-26 and $1 M$ in coarse-grained rocks. Differences in degree of ordering between sudoites from both types of rocks were also observed: in sample CL-26 the basal reflections of sudoite are narrow and symmetrical, whereas they are broader and asymmetrical in sandstones and conglomerates (Figures 2, 3). Similarly, the structural characteristics of sudoite, as observed by TEM, also show differences among the several types of samples, mainly affecting the degree of ordering and the presence of mixed-layer phases. Some of these differences can be related to the different chemical compositions of sudoites, particularly to the influence of increased $\mathrm{Fe}$ contents.

The AEM data for sudoite from sample CL-26 reveal a composition near the ideal formula of sudoite, with a very low Fe content. In contrast, the AEM data for sudoite packets from coarse-grained rocks display notable variations, with $\mathrm{Fe}$ contents greater than those measured in typical sudoites. Indeed, sudoites with such a composition have never previously been reported. An increase in $\mathrm{Fe}$ content is also accompanied by an increase in the $\mathrm{Fe}^{3+} / \mathrm{Fe}^{2+}$ ratio, which is especially evident in sample CL-34. In addition to the higher Fe contents, the analyses of sudoites from samples CL-64 and CL-34 reveal other chemical differences with the microprobe analyses of microscopic sudoites reported in the literature, the most significant being the decrease in the ${ }^{\mathrm{VI}} \mathrm{Al}$ content. Nevertheless, these chemical deviations from the ideal sudoite formula are not reflected either in the tetrahedral charge, or in the octahedral occupancy, both parameters being within the range observed in typical sudoites.

These differences can be explained mainly by the substitution of $\mathrm{Fe}^{3+}$ for $\mathrm{Al}$ in the dioctahedral sheet and of $\mathrm{Fe}^{2+}$ for $\mathrm{Mg}$ in the trioctahedral sheet. Indeed, the AEM data of sudoite from both coarse- and fine-grained samples show some clear correlations between Fe content and $\mathrm{Al}$ and $\mathrm{Mg}$ contents (Figure 10). In the second plot in Figure 10, some points corresponding to sample CL-64 deviate clearly from the general trend. These points, characterized by the low $(\mathrm{Fe}+\mathrm{Mg})$ content 

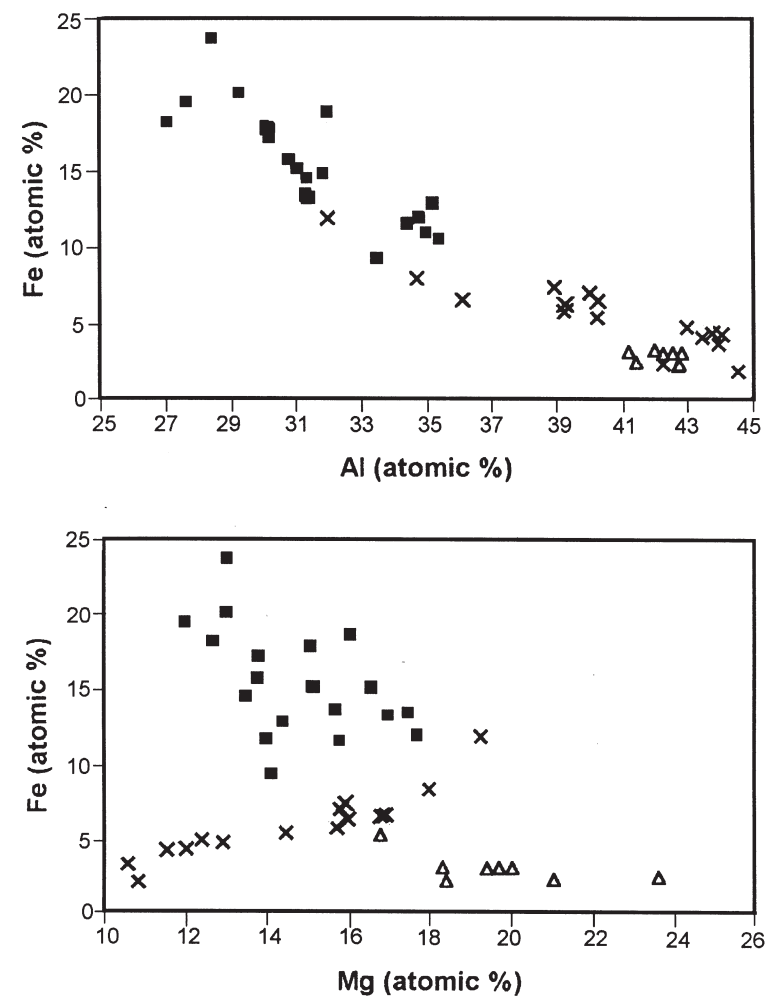

Figure 10. Plots of significant chemical data (AEM) of sudoite. 口: analyses from sample CL-34. $\mathrm{x}$ : analyses from sample CL-64. $\triangle$ : analyses of Mg-rich sudoites from sample CL-26.

and the high Al content, correspond to analyses of dickite-sudoite mixed-layer phases.

Relative to the interstratified phases, the HRTEM images reveal that the increase in $\mathrm{K}$ in the analyses is accompanied by an increase in $10 \AA$ mica layers into the $14 \AA$ sudoite structure. The interstratified structure ranges from randomly ordered sudoite-rich mica-sudoite mixed layers to regular $1: 1$ and 1:2 mica-sudoite interstratifications, the latter being well developed in sample CL-34. The high $\mathrm{Fe}+\mathrm{Mg}$ content in the analyses of these phases suggests, however, that the analyzed areas contain both mixed-layer phases and sudoite. Also in this sample, the increase in Si in the analyses can be correlated with the increase of $9 \AA$ pyrophyllite layers in the lattice-fringe images. Again, the dominant structures are 1:2 pyrophyllite-sudoite mixed layers. Nevertheless, although the pyrophyllite-sudoite ratio is near $1: 2$ in the images, the high $\mathrm{Fe}+\mathrm{Mg}$ content in the analyses of pyrophyllite/sudoite mixed layers suggests that the analyzed areas would contain both sudoite and mixedlayer phases. Finally, the correlated $\mathrm{Al}$ increase and $\mathrm{Fe}+\mathrm{Mg}$ decrease in some analyses from sample CL-64, suggests the presence of dickite-sudoite interstratifications. The lattice-fringe images have not permitted accurate interpretation of this type of interstratification. Nevertheless, the 42 and $56 \AA$ periodicities observed in some packets suggest the presence of 2:1 (or 1:2) and 2:2 dickite-sudoite interstratifications. Indeed, this composi- tion agrees with the AEM data obtained from these packets.

\section{Origin and mechanisms of formation of sudoite}

Mixed-layer phases involving $14 \AA$ trioctahedral chlorite layers are common in both weathering (Brown, 1967; Herbillon and Makumbi, 1975; Proust et al., 1986; Banfield and Murakami, 1988; Murakami et al., 1996) and diagenetic environments (Kerrick and Cotton, 1971; Lee and Peacor, 1985; Ahn et al., 1988; Bettison and Schiffman, 1988). Moreover, as noted by Reynolds (1988), interstratified chlorite phases are frequently regular, and some of the 1:1 chlorite interstratified structures (e.g. corrensite) have been proposed to be a stable phase. The interstratifications described can represent either of two contrasting processes: (1) intermediate steps in the transformation of one of the constituents into the other; and (2) the incomplete evolution of a precursor phase towards the two constituents of the interstratification. The first process has frequently been observed both in weathering and in diagenetic environments. Examples of this process include the 'vermiculitization' of biotite during weathering and the 'illitization' of smectite during diagenesis, among others. 'Vermiculitization' of biotite commonly occurs through the formation of intermediate biotitevermiculite interstratifications (Banfield and Eggleton, 1988), and the illitization of smectite, through the formation of illite-smectite mixed-layers (Peacor, 1992). In both cases there is, however, textural and structural evidence of the process. Thus, the presence of layer transitions or layer termination is common in the structure. The second process is illustrated, for example, by Lee and Peacor (1985) and Ahn et al. (1988) who described mica-chlorite interstratifications formed from precursor smectite, which would lead, at higher temperature, to intergrowths of discrete packets of illite and chlorite.

In the sequences studied, sudoite, muscovite and pyrophyllite coexist in a KI range between 0.30 and 0.42 , suggesting that these three phases are stable in this metamorphic interval. Indeed, Fransolet and Schreyer (1984) concluded from hydrothermal experiments that sudoite is stable at approximately the same temperatures as pyrophyllite. On the other hand, textural evidence, observed by optical microscopy, suggests the transformation of dickite in sudoite, pyrophyllite and muscovite (Lázaro et al. 2003). A similar paragenesis was interpreted as formed from kaolinite by Daniels and Altaner (1990). Therefore, the dickite-sudoite interstratifications can be interpreted as intermediate steps in the dickite to sudoite transformation, whereas both the micasudoite and the pyrophyllite-sudoite interstratifications can be interpreted as intermediate, probably metastable phases, in the dickite $\rightarrow$ muscovite + sudoite and dickite $\rightarrow$ pyrophyllite + sudoite transformations. These two reactions, which probably occurred through a dissolu- 
tion/precipitation process, appear to be complete in some of the rocks studied, given the lack of dickite and the presence of discrete grains of sudoite, muscovite and pyrophyllite. Nevertheless, the TEM study reveals that the progress of the reaction has been variable in several lithotypes, and is also dependent on the depth of the tectonic slices.

Three reactions can be proposed for these transformations:

$$
\begin{aligned}
& \mathrm{Al}_{2} \mathrm{Si}_{2} \mathrm{O}_{5}(\mathrm{OH})_{4}+2 \mathrm{SiO}_{2} \rightarrow \mathrm{Al}_{2} \mathrm{Si}_{4} \mathrm{O}_{10}(\mathrm{OH})_{2}+\mathrm{H}_{2} \mathrm{O} \\
& 5 \mathrm{Al}_{2} \mathrm{Si}_{2} \mathrm{O}_{5}(\mathrm{OH})_{4}+4\left(\mathrm{Mg}^{2+}, \mathrm{Fe}^{2+}\right)+3 \mathrm{H}_{2} \mathrm{O} \rightarrow \\
& \mathrm{Al}_{2} \mathrm{Si}_{4} \mathrm{O}_{10}(\mathrm{OH})_{2}+ \\
& 2 \mathrm{Al}_{3}(\mathrm{Mg}, \mathrm{Fe})_{2}\left(\mathrm{Si}_{3} \mathrm{Al}^{2+} \mathrm{O}_{10}(\mathrm{OH})_{8}+8 \mathrm{H}^{+}\right. \\
& 5.5 \mathrm{Al}_{2} \mathrm{Si}_{2} \mathrm{O}_{5}(\mathrm{OH})_{4}+\mathrm{K}^{+}+4\left(\mathrm{Mg}^{2+}, \mathrm{Fe}^{2+}\right)+2.5 \mathrm{H}_{2} \mathrm{O} \rightarrow \\
& \mathrm{KAl}_{2}\left(\mathrm{Si}_{3} \mathrm{Al}\right) \mathrm{O}_{10}(\mathrm{OH})_{2}+ \\
& 2 \mathrm{Al}_{3}(\mathrm{Mg}, \mathrm{Fe})_{2}\left(\mathrm{Si}_{3} \mathrm{Al}\right) \mathrm{O}_{10}(\mathrm{OH})_{8}+2 \mathrm{SiO}_{2}+9 \mathrm{H}^{+}
\end{aligned}
$$

Although most pyrophyllite in these rocks appears to have formed through reaction 1 , the presence of pyrophyllite-sudoite mixed-layers suggests the more complex reaction 2, which produces sudoite and pyrophyllite simultaneously. On the other hand, reaction 3, which is similar to that proposed by Daniels \& Altaner (1990) for tosudite and sudoite formation from kaolinite, is suggested by the presence of mica-sudoite mixed layers. Reactions 2 and 3 are dependent on the activity of $\mathrm{K}, \mathrm{Mg}$ and $\mathrm{Fe}$ in the fluid phase. $\mathrm{K}$-feldspar, which is a common component in samples from the same sequence, is the more probable source of $\mathrm{K}$ for reaction 3 , and the extent of this reaction would depend on the availability of $\mathrm{K}$ feldspar. Both Fe oxides, very abundant in these rocks, and dolomite were, probably, the source of $\mathrm{Fe}$ and $\mathrm{Mg}$ for reactions 2 and 3 . These reactions, which appear to be simultaneous, also explain the presence of packets containing the three types of layers, as indicated by the AEM data. The chemical differences between the sudoites from the three samples studied can be tentatively related to different initial mineralogy. Indeed, the lack of carbonate in sample CL-34 and the presence of dolomite in samples $\mathrm{Cl}-64$ and $\mathrm{Cl}-26$ suggest that $\mathrm{Mg}$ availability was an important factor controlling the amount and the composition of sudoite.

On the other hand, trioctahedral chlorite is very scarce in these rocks. Lázaro et al. (2003) noted that a notable increase of trioctahedral chlorite occurred in the underlying tectonic slices. The formation of trioctahedral chlorite can also be related to the dickite transformation in those microdomains locally enriched in $\mathrm{Fe}+\mathrm{Mg}$. Indeed, we have not observed intergrowths of sudoite and trioctahedral chlorite, similar to those described by Abad et al. (2003). Figure 11 shows graphically the composition of the phases coexisting in these assemblages. Whereas deviations of the sudoite composition towards the pyrophyllite, muscovite and dickite fields reflect the presence of interstratified phases, there is no evidence of phases intermediate between sudoite and trioctahedral chlorite.

Although the stability field of sudoite has not been clearly established, an approach to the estimation of the temperature of formation of sudoite in these samples can be made based on $P-T$ data of the transformations of kaolinite into either illite or pyrophyllite (Ruiz Cruz et al., 2005). These authors estimated temperatures in the range $150-300^{\circ} \mathrm{C}$ for the assemblages described. The lowest limit would correspond to the dickite-bearing assemblages, and the highest limit to the pyrophyllitebearing ones.

\section{CONCLUSIONS}

Study of sudoites from the Betic Cordillera by TEM/ AEM has allowed the identification of a wide range of sudoite compositions together with some types of sudoite-bearing interstratifications. Sudoite from finegrained rocks contains an Al-rich dioctahedral sheet and a Mg-rich trioctahedral sheet, typical of most previously described sudoites. In contrast, sudoite from coarsegrained rocks displays a variety of chemical compositions, characterized by the presence of an $\mathrm{Al}+\mathrm{Fe}^{3+}$ dioctahedral sheet and a $\mathrm{Mg}+\mathrm{Fe}^{2+}$ trioctahedral sheet, the total Fe content reaching up to 1.8 a.p.f.u. Chemical differences between the sudoites are accompanied by structural differences, including the value of the $b$ parameter (which is higher in the Fe-rich sudoite) and the structural order (which is notably higher in the $\mathrm{Mg}$ rich sudoite).

The presence of metastable mica-sudoite and pyrophyllite-sudoite mixed layers suggests that sudoite formed from dickite in both types of rocks studied, with proposed formation reactions as follows: dickite +

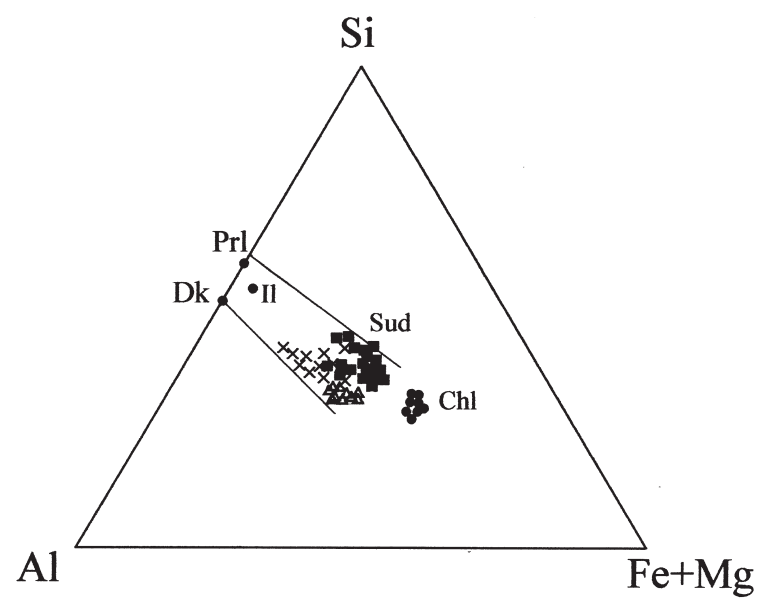

Figure 11. Plot of the chemical characteristic of sudoites on a Si$\mathrm{Al}-(\mathrm{Fe}+\mathrm{Mg})$ ternary diagram. $\mathbf{\square}$ : analyses from sample CL-34. $\mathrm{X}$ : analyses from sample CL-64. $\triangle$ : Mg-rich sudoites from sample CL-26. The composition of coexisting illite (Il), pyrophyllite (Prl), dickite (Dk) and trioctahedral chlorites (Chl) have also been plotted. 
$\mathrm{K}+\mathrm{Fe}+\mathrm{Mg}+\mathrm{H}_{2} \mathrm{O} \rightarrow$ sudoite + white mica $+\mathrm{SiO}_{2}$ and dickite $+\mathrm{Fe}+\mathrm{Mg}+\mathrm{H}_{2} \mathrm{O} \rightarrow$ sudoite + pyrophyllite. The composition of sudoite was probably controlled by the initial mineralogy, especially by the availability of $\mathrm{Mg}$.

\section{ACKNOWLEDGMENTS}

The authors are grateful to $\mathrm{A}$. Inoue, $\mathrm{H}$. $\mathrm{Xu}$ and P. Heaney, whose corrections and suggestions notably improved the manuscript, and to J.L. Baldonedo, A. Gómez and M.M. Abad for help in obtaining the TEM/AEM data. This study received financial support from Project BTE-2003-01382 (Ministerio de Educación y Cultura) and from the Research Group RNM-199 (Junta de Andalucía).

\section{REFERENCES}

Abad, I., Nieto, F., Peacor, D.R. and Velilla, N. (2003) Prograde and retrograde diagenetic and metamorphic evolution in metapelitic rocks of Sierra Espuña (Spain). Clay Minerals, 38, 1-23.

Ahn, J.H., Peacor, D.R. and Douglas, S.C. (1988) Formation mechanisms of illite, chlorite and mixed-layers illite/ chlorite in Triassic volcanogenic sediments from the Southland Syncline, New Zealand. Contributions to Mineralogy and Petrology, 99, 82-89.

Anceau, A. (1992) Sudoite in some Visean (lower Carboniferous) K-bentonites from Belgium. Clay Minerals, 27, 283-292.

Azañón, J.M. (1994) Metamorfismo de alta presión/baja temperatura, baja presión/alta temperatura y tectónica del Complejo Alpujárride (cordilleras Bético-Rifeñas). $\mathrm{PhD}$ thesis, Universidad de Granada, Spain, $331 \mathrm{pp}$.

Bailey, S.W. (1980) Structure of layer silicates. Pp. 28-39 in: Crystal Structure of Clay Minerals and their X-ray identification (G.W. Brindley and G. Brown, editors). Monograph 5, Mineralogical Society, London.

Bailey, S.W. and Lister, J.S. (1989) Structures, compositions and X-ray identification of dioctahedral chlorites. Clays and Clay Minerals, 37, 193-202.

Bailey, S.W. and Tyler, S.A. (1960) Clay mineral associated with the Lake Superior iron ores. Economic Geology, 55, $150-175$

Banfield, J.F. and Eggleton, R.A. (1988) Transmission electron microscopic study of biotite weathering. Clays and Clay Minerals, 36, 47-60.

Banfield, J.F. and Murakami, T. (1988) Atomic-resolution transmission electron microscope evidence for the mechanism by which chlorite weathers to $1: 1$ semi-regular chloritevermiculite. American Mineralogist, 83, 348-357.

Bettison, L.A. and Schiffman, P. (1988) Compositional and structural variation of phyllosilicates from the Point Salt Ophiolite, California. American Mineralogist, 73, 62-76.

Billault, V., Beaufort, D., Patrier, P. and Petit, S. (2002) Crystal chemistry of $\mathrm{Fe}$-sudoites from uranium deposits in the Athabasca basin (Saskatchewan, Canada). Clays and Clay Minerals, 50, 70-81.

Brown, E.H. (1967) The greenschist facies in part of eastern Otago, New Zealand. Contributions to Mineralogy and Petrology, 14, 259-292.

Daniels, E.J. and Altaner, S.P. (1990) Clay mineral authigenesis in coal and shale from the Anthracite region, Pennsylvania. American Mineralogist, 75, 825-839.

Eggleton, R.A. and Bailey, S.W. (1967) Structural aspects of dioctahedral chlorite. American Mineralogist, 52, 673-689.

Enhelhardt, W., Müller, G. and Kromer, H. (1962) Dioktaedrischer Chlorit (Sudoit) in Sedimenten des mit- tleren Keupers von Plochingen (Württemberg). Naturwissenschaften, 49, 205-215.

Fransolet, A.M. and Bourguignon, P. (1978) Di/trioctahedral chlorite in quartz veins from the Ardennes, Belgium. The Canadian Mineralogist, 16, 365-373.

Fransolet, A.-M. and Schreyer, W. (1984) Sudoite, di/ trioctahedral chlorite: A stable low-temperature phase in the system $\mathrm{MgO}-\mathrm{Al}_{2} \mathrm{O}_{3}-\mathrm{SiO}_{2}-\mathrm{H}_{2} \mathrm{O}$. Contributions to Mineralogy and Petrology, 86, 409-417.

Frey, M. (1970) The step from diagenesis to metamorphism in pelitic rocks during Alpine orogenesis. Sedimentology, 15, $261-279$.

Hayashi, H. and Oinuma, K (1964) Aluminian chlorite from Kamikita mine, Japan. Clay Science, 2, 22-30.

Herbillon, A.J. and Makumbi, M.N. (1975) Weathering of chlorite in a soil derived from a chlorite-schist under humid tropical conditions. Geoderma, 13, 89-104.

Islam, A.K.M.E. and Lotse, E.G. (1986) Quantitative mineralogical analysis of some Bangladesh soils with X-ray, ion exchange and selective dissolution techniques. Clay Minerals, 21, 31-42.

Jiang, W.-T. and Peacor, D.R. (1993) Formation and modification of metastable intermediate sodium potassium mica, paragonite, and muscovite in hydrothermally altered metabasites from northern Wales. American Mineralogist, 78, $782-793$.

Kerrick, D.M. and Cotton, W.R. (1971) Stability reactions of jadeite pyroxene in Franciscan metagreywackes near San José, California. American Journal of Science, 271, $350-369$.

Kisch, H.J. (1991) Illite crystallinity: recommendations on sample preparation, X-ray diffraction settings, and interlaboratory samples. Journal of Metamorphic Geology, 9, $665-670$.

Kübler, B. (1968) Evaluation quantitative du métamorphisme par la cristallinité de l'illite. Etat des progrès réalisés ces dernières années. Bulletin de Centre Recherche Pau SNPA, 2, 385-397.

Lázaro, C., Ruiz Cruz, M.D. and Sanz de Galdeano, C. (2003) Características metamórficas del Triásico Maláguide en el sector de Diezma (Sierra Arana, Cordillera Bética). Boletín de la Sociedad Española de Mineralogía, 26, 123-136.

Lee, J.H. and Peacor, D.R. (1985) Ordered 1:1 interstratification of illite and chlorite: a transmission and analytical electron microscopy study. Clays and Clay Minerals, 33, $463-467$.

Lin, C.-Y. and Bailey, S.W. (1985) Structural data for sudoite. Clays and Clay Minerals, 33, 410-414.

Livi, K.J.T., Ferry, J.M., Veblen, D.R., Frey, M. and Connolly, J.A.D. (2002) Reactions and physical conditions during metamorphism of Liassic aluminous black shales and marls in central Switzerland. European Journal of Mineralogy, 14, $647-672$.

Lorimer, G.W. and Cliff, G. (1976) Analytical electron microscopy of minerals. Pp. 506-519 in: Electron Microscopy in Mineralogy (H.R. Wenk, editor). SpringerVerlag, New York.

Mäkel, G.H. (1985) The geology of the Maláguide complex and its bearing on the geodynamic evolution of the Betic-Rif orogen (Southern Spain and Northern Morocco). Gua Papers of Geology, 22, 263 pp.

Maxwell, D.T. and Hower, J. (1967) High-grade diagenesis and low-grade metamorphism of illite in the Precambrian Belt series. American Mineralogist, 52, 843-857.

Merriman, R.J. and Peacor, D.R. (1999) Very low-grade metapelites: mineralogy, microfabrics and measuring reaction progress. Pp. 10-60 in: Low-grade Metamorphism (M. Frey and D. Robinson, editors). Blackwell Science, Oxford, UK. 
Murakami, T., Isobe, H., Sato, T. and Ohnuki, T. (1996) Weathering of chlorite in a quartz-chlorite schist: I. Mineralogical and chemical changes. Clays and Clay Minerals, 44, 244-256.

Newman, A.C.D. and Brown, G. (1987) The chemical constitution of clays. Pp. 1-128 in: Chemistry of Clays and Clay Minerals (A.C.D. Newman, editor). Monograph 6, Mineralogical Society, London.

Peacor, D.R. (1992) Diagenesis and low-grade metamorphism of shales and slates. Pp. 335-380 in: Minerals and Reactions at the Atomic Scale (P.R. Buseck, editor). Reviews in Mineralogy, 27, Mineralogical Society of America, Washington, D.C.

Proust, D., Eymery, J.P. and Beaufort, D. (1986) Supergene vermiculitization of a magnesian chlorite: iron and magnesium removal process. Clays and Clay Minerals, 34, $572-580$.

Reynolds, R.C. (1988) Mixed-layer chlorite minerals. Pp. 601-629 in: Hydrous Phyllosilicates (S.W. Bailey, editor). Reviews in Mineralogy, 19. Mineralogical Society of America, Washington D.C.

Ruiz Cruz, M.D. and Rodríguez Jiménez, P. (2002) Correlation between crystallochemical parameters of phyllosilicates and mineral facies in very low-grade metasediments of the Betic Cordillera (Spain): A synthesis. Clay Minerals, 37, $169-185$.

Ruiz Cruz, M.D., Sanz de Galdeano, C. and Lázaro, C. (2005) Metamorphic evolution of Triassic rocks from the transition zone between the Maláguide and the Alpujárride complexes (Betic Cordilleras, Spain). European Journal of Mineralogy, 17, $81-91$.

Sanz de Galdeano, C., Delgado, F. and López-Garrido, A.C. (1995a) Unidades alpujárrides y maláguides al NE de
Granada (Cordillera Bética). Geogaceta, 18, 27-29.

Sanz de Galdeano, C., Delgado, F. and López-Garrido, A.C. (1995b) Estructura del Alpujárride y del Maláguide al NW de Sierra Nevada (Cordillera Bética). Revista de la Sociedad Geológia de España, 8, 239-250.

Sanz de Galdeano, C., Delgado, F., López-Garrido, A.C. and Martín-Algarra, A. (1995c) Appartenance alpujárride proposé de l'unité de la Mora au NE de Grenade (Cordillère Bétique, Espagne). Comptes Rendus de l'Academie des Sciences Paris, 321 (IIa), 893-900.

Sanz de Galdeano, C., Andreo, B., García-Tortosa, F.J. and López-Garrido, A.C. (2001) The Triassic palaeogeographic transition between the Alpujárride and Maláguide complexes, Betic-Rif Internal Zone. Palaeo, 167, 157-173.

Sudo, T. and Sato, M. (1966) Dioctahedral chlorite. Proceedings of the International Clay Conference, Jerusalem, 1, 33-39.

Theye, T. and Siedel, H. (1993) Chloritoid, carpholite and sudoite in very low-grade metamorphic rocks of the Wippra metamorphic zone (Harz, Germany). Neues Jahrbuch für Mineralogie, Monatshefte, 1993, 73-96.

Theye, T., Siedel, H. and Vidal, O. (1992) Carpholite, sudoite and chloritoid in low-grade high-pressure metapelites from Crete and the Peloponnese, Greece. European Journal of Mineralogy, 4, 487-507.

Warr, L.C. and Rice, H.N. (1994) Interlaboratory standarization and calibration of clay minerals crystallinity and crystallite size data. Journal of Metamorphic Geology, 12, $141-152$

(Received 4 February 2005; revised 30 June 2005; Ms. 1009; A.E. Peter J. Heaney) 